\title{
Shakespearean Ballads in Thomas Percy's Reliques of Ancient English Poetry \\ Transition from Oral Songs to \\ Printed Historical Documents
}

\author{
Minoru Mibara
}

\begin{abstract}
Thomas Percy's ballad collection, Reliques of Ancient English Poetry, marks a point of intersection between balladry and Shakespeareana, which both went through a transitional phase from vocal performance to literary undertaking in the eighteenth century. In the Reliques, ballads that had been orally transmitted by minstrels were changed into validated printed sources for a scholarly project. This transition helped eighteenth-century editors gain a historical understanding of Shakespeare and emend his traditionally received texts. These editors were persuaded to use the ballads in the Reliques as reliable sources for their emendation since they were printed as authoritative documents that were useful for their academic editions of Shakespeare. They gained easy textual access to the printed ballads in the Reliques to search for contextual or emendatory materials. A comparison of four Shakespeare-related ballads in the Reliques ("King Cophetua and the Beggar-Maid", "Take Thy Old Cloak about Thee", "Willow, Willow, Willow", and "The Passionate Shepherd to His Love") to their counterparts in editions of Shakespeare reveals that the ballads that were printed as historical documents in the Reliques advanced the editors' contextual illustration of Shakespeare and that they authorized the emendation of the textus receptus. This article focuses on the effect of the historical information provided by Percy's printed ballads on George Steevens's and Edmond Malone's contextualization of Shakespeare and on their emendation of Shakespearean texts. In addition, it concentrates on the possibility that Edward Capell referred to Shakespearean ballads in Percy's Reliques combined with old Quarto editions of Shakespeare's works.
\end{abstract}

$\mathrm{B}_{\mathrm{s}}$ allad songs and Shakespearean Plays were seen as the embodiment of oral culture before the eighteenth century. Ballads were sung by minstrels, and the performance of Shakespearean plays likewise maintained performers' voices. In addition to having orality in common, 
they exhibited cross-interaction because Shakespeare made frequent use of ballads in his plays. The two genres were closely tied to each other, reaching beyond the boundary between them.

In the mid-sixteenth century, when Shakespeare was born, balladry was not yet established as a special category. In his History of English Poetry (1774-81), Thomas Warton illustrates how indistinctive "[a] romance, or History, versified" and religious subjects were under the title of ballad (Warton [1774-81] 1998, 3:423). His explanation also accounts for the mid-sixteenth century thespian situation in which "[a] play or interlude was sometimes called a ballet" (Warton [1774-81] 1998, 3:423). According to the OED, "ballet" was a commonly used spelling of the word "ballad" in the sixteenth and seventeenth centuries (Oxford English Dictionary, 2nd ed., s.v. "ballad"). Thus, Shakespeare's age was marked by this transboundary relationship between play and ballad.

Gerald Porter brackets Shakespearean plays with contemporary ballads $(1997,169)$. Porter's argument is based on his belief that "[t]here was also a dense relation between working life, popular song and the theatre" in Shakespeare's age $(1997,168)$. Porter discusses the close relationship between popular ballads and Shakespearean plays in terms of orality (1997, 173-74). This is corroborated by Walter J. Ong's viewpoint, which argues that "[t]hough Renaissance humanism invented modern textual scholarship and presided over the development of letterpress printing, it also harkened back to antiquity and thereby gave new life to orality" (ONG 1982, 115). ${ }^{1}$

In the eighteenth century, however, the plays and ballads were forced to impair their close-knit connection with oral culture. As oral culture was completely replaced by printing culture in the eighteenth century, Shakespearean plays and balladry were deprived of their orality. Under the dominance of literacy over orality, they shared the same destiny since they were fixed on the printed page. ${ }^{2}$

Once ballads and Shakespearean plays lost their orality, the shift from performance to print strengthened their feature as literary materi-

1. In Rhetoric, Romance, and Technology Ong claims that "oral residue is of special importance on the Tudor scene, for [. . . ] the world of the Tudor writer shows a more massive concentration of oral residue than that of earlier ages" $(1971,47)$.

2. David Scott Kastan argues that the Shakespeare sought by editors in the eighteenth century was "explicitly an author not a playwright" and that as a result, Shakespearean plays were "not scripts to be performed [ . . ] but plays to be read [. . .]" $(2001,96)$. Eric Nebeker suggests that the relationship between ballads and print became strengthened as early as in the sixteenth century $(2011,4-5)$. 
als. Shakespeare's plays and ancient ballads no longer had to retain their vocality when they were transformed into printed and academically treated texts. Thomas Percy destroyed the orality of ballad literature by changing its fragile vocality into secure, printed texts that were worthy of publication in his ballad collection, Reliques of Ancient English Poetry. ${ }^{3}$ Paula McDowell argues that Percy pointed to "an evolutionary model of media shift (the idea of a shift 'from' oral 'to' literate society)" (2010, 243). Through this transitional procedure, ancient ballads presented as validated, printed sources for a scholarly project helped eighteenth-century editors contextualize Shakespeare and emend his traditionally received texts. In addition, the ballads helped editors verify whether their contextualization and emendation of Shakespeare was appropriate; thus, they could confirm their relevancy.

In the Reliques, Shakespearean ballads were displayed as historical documentary records for contextualizing Shakespeare rather than as vividly voiced reminders that Shakespeare was fascinated by what minstrels sang. ${ }^{4}$ Percy's keen awareness of the historical context that surrounded Shakespeare gave occasion to his attempt to focus on Shakespearean ballads in the Reliques. Percy believed that some of the ballads Shakespeare used in his plays were key to understanding Shakespeare contextually. ${ }^{5}$ I aim to highlight the fact that Percy treated ballads as academically invaluable historical materials. In endeavoring to present old ballads as guides for the contextualization of Shakespeare, he "established certain types of balladry as worthwhile objects of genteel appreciation and scholarly study", as McDowell argues (2006, 163).

This scholarly designed venture led to the emendation of traditionally received Shakespearean texts, although Arthur Sherbo puts forth the idea that "Percy, unlike too many other Shakespeareans of his time, rarely suggests an emendation; he is not a textual scholar" (1986, 41). Shakespeare editors were persuaded to use the ballads in the Reliques as reliable sources for their emendation since they were printed as authoritative documents that were useful for their academic editions of Shakespeare. The editors

3. The five editions of the Reliques were published in $1765,1767,1775,1794$, and 1812 , respectively.

4. Each volume of the Reliques consists of three books respectively: since the Reliques is a three-volume collection, it has nine subcategories in total. Shakespearean ballads are featured in the second book of the first volume in the Reliques.

5. Percy points out, in his letter to Richard Farmer, that Thomas Warton used old romances "for clearing up passages in our old Poets" (BRoокs 1946, 7). This method was applied to Percy's attempt to contextualize Shakespeare on the basis of old ballads. 
gained easy textual access to the printed ballads in the Reliques when they searched for contextual or emendatory material, that is, historical information obtained literately and not orally.

The comparison of four Shakespearean ballads in the Reliques ("King Cophetua and the Beggar-Maid", "Take Thy Old Cloak about Thee", "Willow, Willow, Willow", and "The Passionate Shepherd to His Love") to different editions of Shakespeare reveals that printed ballads, as historical documents, advanced Percy's historical understanding of Shakespeare as well as that of his contemporary editors, and they authorized the emendation of traditional Shakespearean texts. ${ }^{6}$ This article tackles the effect of the historical information provided by Percy's printed ballads on George Steevens's and Edmond Malone's historical criticism and on their emendation of Shakespearean texts. It likewise explores the possibility that Edward Capell, a revolutionist in editing Shakespeare (WALsh 1997, 182), referred to Shakespearean ballads in Percy's Reliques combined with older Quarto printed editions of Shakespeare's works.

Nick Groom correlates Percy's editing of Shakespearean ballads to "an attempt to woo Johnson back to the Reliques" $(1999,185)$. He argues that Percy's Reliques was an enterprise meant to conduce to "Johnson's edition of Shakespeare, which did contain several such notes contributed by Percy" (1999, 185). By focusing on Shakespeare editors subsequent to Johnson, I illustrate that Shakespearean ballads, submitted as printed historical materials, were instrumental in the development of the historical criticism that was favored by Capel, Steevens, and Malone.

\section{Percy's Influence on Steevens's and Malone's Historical Criticism: "King Cophetua and the Beggar-Maid" and Romeo and Juliet}

In the headnote to "King Cophetua and the Beggar-Maid", Percy explains that Shakespeare alluded to this ballad in his Romeo and Juliet (1765, 1:166). He suggests the possibility that the thirteenth line of this ballad contained

6. The editions of Shakespeare to be collated comprise Nicholas Rowe's (1709), Alexander Pope's (1725), Lewis Theobald's (1733), William Warburton's (1747), Samuel Johnson's (1765), Edward Capell's (1768), George Steevens's (1773), and Edmond Malone's (1790), in addition to the Quartos published during and immediately after Shakespeare's lifetime, and to the First Folio (F1) published in 1623, the first collection of Shakespeare's plays. The Shakespeare Folios are made up of the first, second (1632), third (1663), and fourth (1685). 
original Shakespearean writing of "trim", which "the players or printers, not perceiving the allusion, might alter to TRUE" (1765, 1:166). The Reliques places the word at the beginning of the second stanza:

The blinded boy, that shootes so trim,

From heaven downe did hie;

He drew a dart and shot at him,

In place where he did lye:

("King Cophetua and the Beggar-Maid", 13-16; Percy 1765, 1:167)7

Editions of Shakespeare, from the 1597 First Quarto (Q1) to Edmond Malone's edition, describe a young archer named Abraham Cupid or Adam Cupid. The list of quotations from the editions reveals that editors before Steevens were unaware of this allusion, with the exception of the editor of the First Quarto:

young Abraham: Cupid hee that shot so trim

(Q1, Rom., C4v)

Young Abraham: Cupid he that shot so true

(Q2, Rom., D1v) $)^{8}$

Young Abraham Cupid he that shot so true

(F1, Rom., 2.1. TLN 763)

Young Abraham Cupid, he that shot so true

(Rowe, Rom., 2.2. 5:2094)

(Young Abraham Cupid, he that shot so true

(Pope, Rom., 2.2. 6:268)

(Young Abraham Cupid, he that shot so true

(Theobald, Rom., 2.1. 7:151)

(Young Abraham Cupid, he that shot so true

(Warburton, Rom., 2.1. 8:33)

(Young Abraham Cupid, he that shot so true

(Johnson, Rom., 2.1. 8:37)

Young Abraham Cupid, he that shot so true

(Capell, Rom., 2.3. 10:C1r)

7. "13-16" indicates line numbers.

8. Q2 refers to the 1599 Second Quarto.

9. This citation is from Act 2, Scene 1 . TLN signifies the Through Line Numbering of the First Folio. All quotations from the First Folio are taken from HinMAN 1968. 
(Young Adam Cupid, he that shot so trim (Steevens, Rom., 2.1. 10:43) 10 $^{10}$

Young Adam Cupid, he that shot so trim

(Malone, Rom., 2.1. 9:54)

Judging from the agreement regarding the word "trim" between the First Quarto and the Reliques, it is clear that Percy restored the reading of the First Quarto. He refused the submissive adoption of what earlier editors had accepted as the received reading. Horace Howard Furness mentions that Percy did not know "that the word was found in (Q1)" (SH AKESPEARE 1871, 89). Even if he did not notice the appearance of "trim" in the First Quarto, which is unlikely in light of the fact that he owned the Quartos and the Folios, ${ }^{11}$ he revived the reading "trim" by using the ancient ballad as contextual material. This contextualization exerted his influence on Steevens and Malone, who thus became aware of the relationship between this ballad and Romeo and Juliet. Percy's Reliques, which they consulted for their editions, promoted their historical criticism of Shakespeare. Percy prompted Steevens and Malone to improve the received text of Shakespeare by offering a printed version of this ballad as contextual foundation for their textual emendation.

In addition to his acceptance of the revival of "trim", Steevens added more information to the printed historical material that was made available by Percy. After introducing Percy's explanation of "the first editors", who, without "perceiving the allusion, would naturally alter [the word trim] to true", Steevens's 1793 edition of Shakespeare offers two citations from Thomas Churchyard's "The Siege of Leith" (1560): "Made sallies forth, as tryme men might do"; "And showed themselves trimme souldiours as I ween" (Johnson and Steevens 1793, 14:394). ${ }^{12}$ As a result, Steevens could prove that the word "was an epithet formerly in common use" (JoHnson And Steevens 1793, 14:394). The fourth edition of the Reliques, published

10. Johnson and Steevens 1773. In his 1766 edition, Steevens follows his antecedents about this line: "Young Abraham: Cupid he that shot so true [. . .]" (1766, 4:G6r). His subsequent editions (1773, 1778, 1785, and 1793) are revised versions of Samuel Johnson's 1765 Shakespeare (DE BRU yn 2012, 352-53, 358). In the comparison this article makes, quotations from Steevens's Shakespeare are drawn from the 1773 edition.

11. Letters between Percy and Malone demonstrate that Percy possessed the Folios and the Quartos (Tillotson 1944, 8-9, 16, 28).

12. Steevens identifies the publication date of this poem as 1575 . As to the detailed information about Thomas Churchyard, see HAger 2005, 86. 
in 1794, reveals that "it has been discovered that SHOT SO TRIM was the genuine reading" (PERCY 1794, 1:198). In fact, this declaration had already been made in the third edition of the Reliques (1775), which urges readers to "see Steevens's Shakespeare" (Percy 1775, 1:184), although Steevens's 1773 edition lacks citations from Churchyard's "The Siege of Leith" (JohnSON AND STEEVENS 1773, 10:44). ${ }^{13}$

In an attempt to gain a contextual understanding of Shakespeare, Malone's edition offers a stanza of the ballad that "Shakspeare had particularly in view", as Malone states in a footnote to Romeo and Juliet (1790, 9:55):

"The blinded boy that shoots so trim,

"From heaven down did hie,

"He drew a dart and shot at him,

"In place where he did lie;"

This stanza, which is identical to Percy's "King Cophetua and the BeggarMaid", "supports [. . . ] the reading trim, which is found in the First Quarto 1597 , and which in the subsequent copies was changed to true" (MAlone 1790, 9:55). Malone's contextualization and emendation of Shakespeare agrees with Percy's renunciation of the traditionally received word "true".

Moreover, in the headnote to another Shakespearean ballad in the Reliques, "Adam Bell, Clym of the Clough, and William of Cloudesly", Percy sympathizes with the conjecture that "Abraham Cupid' in Romeo and Juliet, A 2. sc. I. should be 'ADAM Cupid,' in allusion to our archer" (1765, 1:130). Steevens and Malone acted on Percy's suggestion. The reason is provided in their notes: Steevens's alteration was based on Thomas Gray's assertion that this youngster alludes to the renowned archer Adam Bell (JoHnson And Steevens 1773, 10:43); Malone's modification follows after the alteration "suggested by Mr. [John] Upton" (1790, 9:54). The two Shakespeare editors confirm that Percy's theory was corroborated by Gray and Upton. In consideration of their notes, which both refer to the Reliques, Percy's influence supposedly resulted in their association of "Adam", not "Abraham", with the young archer.

Steevens and Malone were convinced that Percy's printed historical material constituted authentic historical records that triggered the contex-

13. Steevens's 1778 and 1785 editions also fail to take the quotations from "The Siege of Leith". See Johnson And Steevens 1778, 10:52; Johnson And Steevens 1785, 10:54-55. 
tualization of Shakespeare and that they hence were authorized to emend the textus receptus. This interaction between ballads and Shakespeareana testifies to the progress of the historical criticism of Shakespeare leveraged by print technology and intended for scholarly projects.

Percy's attempt to display ballads as printed contextual material is repeatedly put forth in "King Cophetua and the Beggar-Maid". Percy makes the bold proposal that "Zenelophon", a name given to a beggar in Love's Labour's Lost, to which Shakespeare correlates this ballad, should be changed into "Penelophon", which appears in this ballad (1767, 1:186-87).14 All editions of Shakespeare opt for "Zenelophon". Steevens's and Malone's editions, although they support their predecessors' reading of "Zenelophon", introduce Percy's claim in their notes to Love's Labour's Lost (JohNson and Steevens 1773, 2:388; Malone 1790, 2:360).

\section{“Take Thy Old Cloak about Thee" and Otbello}

In its headnote, "Take Thy Old Cloak about Thee" announces that this ballad overlaps with the ballad Shakespeare cited in his Othello (PERCY 1765, 1:172). The first line of the seventh stanza in the Reliques is juxtaposed with its counterpart in the editorial source, Percy's Folio Manuscript (MS), as follows: ${ }^{15}$

King Stephen was a worthy peere,

(Reliques, "Take Thy Old Cloak about Thee", 49;

Percy 1765, 1:174)

"King Harry was a verry good K[ing;

(Folio MS, "Bell My Wiffe", 49;

Hales and Furnivall $1867-68,2: 324)^{16}$

14. Percy $1775,1: 188-89 ; 1794,1: 202 ; 1812,1: 206$. This proposal is lacking in the first edition of the Reliques.

15. Groom explains Percy's Folio Manuscript as a "seventeenth-century commonplace book of popular songs and ballads" $(1999,20)$. It is possible "to date the compilation of the manuscript to the 1640s" (Donatelli 1993, 116). Percy found the MS on the verge of ruin at his friend's house. Roughly a century after the first edition of the Reliques was published in 1765, John W. Hales and Frederick J. Furnivall printed the MS.

16. The parentheses in the word "K[ing;]" were inserted by Hales and Furnivall. 
The eighteenth-century editions of Shakespeare are collated with the 1622 Quarto (Q1) and the First Folio below:

King Stephen was a worthy peere

(Q1, Oth., E4r)

King Stephen was and-a worthy Peere

(F1, Oth., 2.3. TLN 1201)

King Stephen was and-a worthy Peer

(Rowe, Oth., 2.1. 5:2584)

King Stephen was and-a worthy peer

(Pope, Oth., 2.10. 6:513)

King Stephen was an a worthy peer

(Theobald, Oth., 2.3. 7:416)

King Stephen was an a worthy peer

(Warburton, Oth., 2.10. 8:319)

King Stephen was an a worthy peer

(Johnson, Oth., 2.11. 8:373)

King Stephen was a worthy peer

(Capell, Oth., 2.3. 10:T1r)

King Stephen was a worthy peer

(Steevens, Oth., 2.3. 10:416)

King Stephen was a worthy peer

(Malone, Oth., 2.3. 9:514)

Percy's headnote to this ballad reads: "[t]his curiosity is preserved in the Editor's folio MS but not without corruptions, which are here removed by the assistance of the Scottish Edit[ion]" (1765, 1:172). Henry B. Wheatley, who reedited the fourth edition of Percy's Reliques in the Victorian era, attributes "the Scottish Edit[ion]" to a ballad in Allan Ramsay's Tea Table Miscellany, in which the king is named "Robert" (Percy 1891, 1:195). Percy adopted neither "King Harry" nor "King Robert" but instead assumed the reading that the Shakespeare editors had received. Percy tried to reverse the process whereby "a worthy peere" in the First Quarto was later reshaped into "and-a worthy peer" or "an a worthy peer". The reading of "a worthy peere" was accepted by Steevens and Malone. ${ }^{17}$

17. Capell adopted Percy's reading, too. I would like to suggest that Capell consulted both the First Quarto and the Reliques for his edition of Shakespeare, in consideration of Capell's relationship with Percy. See the following sections. 
As far as "King Stephen" is concerned, Percy's historical understanding of Shakespeare involves an alteration of contextual material to match it with the Shakespearean text. Instead of presenting the material offered by the Folio MS or Ramsay's ballad, Percy printed a more authoritative version, namely a text he believed Shakespeare had used. Percy's enthusiasm to contextualize Shakespeare was inseparably linked to his ambition to reconstruct a version that was seen by Shakespeare himself firsthand. Percy aimed to fulfil his goal to present ancient ballads in the same form as how Shakespeare had known them. In other words, his task was a conjectural reconstruction of the ancient ballads to which Shakespeare must have referred. Through this editorial procedure of conjecturing and reconstructing original texts, Percy selected "Stephen" as included in the old ballad that had been familiar to Shakespeare. He renounced the readings of "Harry" and "Robert" in his Folio MS and Ramsay's Tea Table Miscellany.

This conjecture is also mirrored in Percy's attempt to offer the reading of "a worthy peere", which is identical to the Quarto reading. As an authentic text, which he judged to be closest to the original text that had been witnessed by Shakespeare, Percy presented the reading in the Reliques, resulting in Steevens and Malone's acceptance of it in their editions of Shakespeare. Percy's ballad revealed their return to the text of the First Quarto to be validated.

In his edition of Othello, E. A. J. Honigmann doubts that "Percy printed the ballad exactly as Shakespeare knew it [. . .]" (Shakespeare [1997] 1999, 337). It may be impossible to reproduce this original ballad in the form that Shakespeare used. However, the undertaking of printing this ballad in the Reliques reflects Percy's enterprise to reconstruct, by means of conjecture, what he thought to have been "the ballad exactly as Shakespeare knew it".

Percy occasionally took a step forward in restoring a hypothetical, invisible text of Shakespeare's original sources. This demonstrates his editorial intention to provide the most authoritative printed historical documents to the Shakespeare editors through processes of eclectic arrangements of contextual materials and on the basis of conjectural reconstructions.

\section{Effect of the Reliques on Capell's Shakespeare Edition: Rivalry between Percy and Capell}

The following sections propose the hypothesis that Percy guided Capell's historical criticism of Shakespeare despite the fact that the text of his edi- 
tion of Shakespeare excludes any reference to Percy's Reliques. ${ }^{18}$ Percy's influence on Capell's edition of Shakespeare is confirmed by their discussion of Shakespearean ballads. In his letter to Thomas Warton, written in June 1761, Percy implies that "Shakespeare took the plots of many other of his plays from Old Ballads" and that Capell possessed "an Old Poem On the Subject of Romeo and Juliet" (Robinson And Dennis 1951, 16-17). As is revealed in Percy's letter to a Shakespearean scholar, Richard Farmer, written in March 1765, Percy and Capell's argument about ancient ballads caused frictions between them. Capell refused to accept Percy's "opinion about the Date of the Nut-brown Maid"; they "exchange a few words, but he [Capell] never invites me [Percy] to call on him: for he charges me with the inexpiable Crime of 'forestalling him in the Ballad of Titus Andronicus'" (Brooks 1946, 87). ${ }^{19}$ This rivalry, which unfolded in the situation where they "have had a final rupture and are never to speak to each other more" (Brooks 1946, 106), ${ }^{20}$ proves that Capell was fully aware of Percy's editing of Shakespearean ballads in the Reliques. Henceforth, through a collation of the Reliques with the editions of Shakespeare, I will explore how Percy helped Capell renounce traditionally received readings and return to the early Quarto editions of Shakespeare's works. The two ballads, "Willow, Willow, Willow" and "The Passionate Shepherd to His Love", are examined for the collation.

\section{"Willow, Willow, Willow" and Otbello}

In the Reliques, Percy focuses his attention on "Willow, Willow, Willow", from which "Shakespeare has taken his song of the WILLOW, in his OTHELLO, A. 4. s. 3. though somewhat varied and applied by him to a female character" $(1765,1: 175) .{ }^{21}$ The editions of Shakespeare exhibit the first lines of this song as follows:

18. I found out about this fact through Chadwyck-Healey's EDITIONS AND ADAPtations of ShaKespeare.

19. In February 1765, Percy published "Titus Andronicus's Complaint" in the first edition of the Reliques. See Percy 1765, 1:203-9.

20. This rift is revealed in Percy's letter to Farmer, written in March 1766.

21. Honigmann argues that despite the fact that the Willow Song in Shakespeare's Othello derives from "an old ballad in Percy's Reliques", it is not wise to consider that "Percy's version gives the ballad verbatim as Shakespeare found it" (ShaKespeare [1997] 1999, 339). 
The poore Soule sat singing, by a Sicamour tree

(F1, Oth., 4.3. TLN 3011)

The poor Soul sat Singing, by a Sycamore Tree

(Rowe, Oth., 4.2. 5:2630)

The poor soul sat singing by a sycamore tree

(Pope, Oth., 4.13. 6:570)

The poor soul sat singing by a sycamore-tree

(Theobald, Oth., 4.2. 7:473)

The poor soul sat singing by a sycamore-tree

(Warburton, Oth., 4.13. 8:383)

'The poor soul sat singing by a sycamore-tree

(Johnson, Oth., 4.13. 8:446)

The poor soul sat sighing by a sycamore tree

(Capell, Oth., 4.3. 10:Y5v)

"The poor soul sat singing by a sycamore-tree

(Steevens, Oth., 4.3. 10:491)

The poor soul sat sighing by a sycamore tree

(Malone, Oth., 4.3. 9:609)

The Reliques presents an equivalent to the beginning of this song, as sung by Desdemona in Othello:

A Poore soule sat sighing under a sicamore tree

(“Willow, Willow, Willow", 1; Percy 1765, 1:176)

Capell and Malone used the word "sighing" instead of "singing", while the other editors adopt the latter in their editions. The Reliques corresponds with Capell's edition, which may be a sign of the Reliques's influence on Capell.

Here we must keep in mind that Capell "went back to the originals and bypassed traditionary textual corruption" (WALsH 1997, 178), which accumulated in the eighteenth century editions of Shakespeare. Capell's edition is consistent with the 1630 Quarto of Othello (Q2). Malone's note explains that "sighing" derives "from a quarto of no authority printed in 1630 ",22 and from "the black-letter copy of this ballad in the Pepys Collec-

22. Honigmann categorizes "singing" as a reading in a corrected state of Folio, and "sining" as what is presented by an uncorrected state of Folio. He also points out that "sighing" is the reading of the Second Quarto (SH A Kespeare [1997] 1999, 291). 
tion, which Dr. Percy followed" (1790, 9:609). ${ }^{23}$ The Second Quarto offers the following reading as the first line of Desdemona's song: "The poore soule sate sighing by a sicamour tree" (Sh a Kespe Are 1630, 77). Pepys's ballad, "A Louers Complaint Being Forsaken of His Loue", presents the following in its first line: "A Poore soule sat sighing vnder a Sicamore tree" (Weinstein $1992,2.1: 55){ }^{24}$

The textual accordance between the Reliques, Capell's edition, and the Second Quarto fails to preclude the possibility that Capell consulted, with regard to this word, Percy's Reliques and the 1630 Quarto, whose reading Capell judged to be uncorrupted and correct; the Reliques was the only eighteenth-century source to introduce the reading of "sighing" when Capell published his edition of Shakespeare. Percy's Reliques fostered Capell's emendation, his return to the reading of the Second Quarto, by presenting this ballad as printed documentary evidence and ensured Capell that it would be validated.

\section{"The Passionate Shepherd to His Love" and The Merry Wives of Windsor}

"The Passionate Shepherd to His Love", which Percy ascribed to Christopher Marlowe and not to Shakespeare (Percy 1765, 1:199), has a portion parallel to Sir Hugh Evans's song in The Merry Wives of Windsor. The Reliques presents the following text:

There will I make thee beds of roses

With a thousand fragrant posies,

("The Passionate Shepherd to His Love", 9-10;

Percy 1765, 1:201)

Virtually no editors of Shakespeare chose the phrase "beds of roses" Percy adopted in the Reliques:

23. I would like to take into account the possibility that Percy consulted the Quartos and the Folios as well as the Pepys Collection. The black-letter ballad was published about 1615 (FumERTON 2003).

24. The second volume of Weinstein's Catalogue comprises two volumes: the first and second parts. "2.1" signifies the first part of the second volume. See also FUMERTON 2003. 
There will we make

our Peds of Roses: and a thousand fragrant posies. ...

(F1, Wiv., 3.1. TLN 1175-76)

There will we make our Peds of

Roses, and a thousand fragrant Posies. . . .

(Rowe, Wiv., 3.1. 1:154)

There will we make our peds of roses,

And a thousand fragrant posies.

(Pope, Wiv., 3.1. 1:270)

There will we make our peds of roses;

And a thousand fragrant posies.

(Theobald, Wiv., 3.1. 1:261)

There will we make our peds of roses;

And a thousand vragrant posies.

(Warburton, Wiv., 3.1. 1:294)

There will we make our peds of roses;

And a thousand vagrant posies.

(Johnson, Wiv., 3.1. 2:498)

there will we make our beds of roses, and a thousand fragrant posies.

(Capell, Wiv., 3.1. 1:N4v)

There will we make our peds of roses;

And a thousand vragrant posies.

(Steevens, Wiv., 3.1. 1:249)

There will we make our peds of roses, And a thousand fragrant posies.

(Malone, Wiv., 3.1. 1.2:246)

Capell's endeavor to return to the early Quarto editions is reflected in giving "beds of roses" instead of "peds of roses". The source of Capell's "beds of roses" can be attributed to the 1602 Quarto (Q1): 
And then she made him bedes of Roses, (trobes,

And a thousand fragrant poses,

To shallow riueres....

(Q1, Wiv., D2v)

The reading of the First Quarto "bedes of Roses" is in agreement with Capell's edition. Not only the First Quarto but also Percy's Reliques give grounds for Capell's selection of these words that were avoided by other editors. Capell's emendation of the words "peds of roses" by relying on the authority of the First Quarto can be validated with the aid of Percy's Reliques. As printed documentary evidence, "The Passionate Shepherd to His Love" in the Reliques authorized Capell to emend the received text, with the result that he presumably persuaded himself to return to the text of the First Quarto.

As far as the word "sigh" and the phrase "beds of roses" are concerned, Percy's Reliques reassured Capell the validity of their use in his edition of Shakespeare. Both the early Quarto editions and the ancient ballads in the Reliques provided much of the material for Capell's emendation of Shakespearean texts. In the Reliques, Percy transformed ballads that were never secure enough for publication into authoritative, printed versions of historical documents. Percy's ambition to present the ballads as foundation for the emendation of Shakespearean texts stimulated and endorsed Capell's restoration of the Quarto texts of Shakespeare.

\section{Conclusion}

Percy's Reliques marks a point of intersection between balladry and Shakespeareana, which both underwent the transition from orality to literacy in the eighteenth century. Ballads and Shakespearean plays were vocalized by singers and performers before the century, but they subsequently went through a transitional phase from vocal performance to literary and scholarly undertaking. In the Reliques, ballads that had been orally transmitted by minstrels acquired "a new and unembarrassed status both as an authenticating source and as an archival domain", as put forth by Maureen McLane (2010, 253). This implies that a minstrel without a singing voice who was confined to printed pages was no longer "the living transmitter" (McLAne 2010, 253) but rather a voiceless provider of historical documentary records in print about Shakespeare as well as a catalyst of the emendation of his text. When readers were detached from oral culture, 
Shakespearean ballads changed from songs that appealed to the ears of the audience to printed documents intended for readers' eyes in Percy's Reliques. This transition assisted the progress of the historical understanding and textual emendation of Shakespeare in the eighteenth century. The transformation determined the discontinuity of oral history transmitted by minstrels and enhanced the development of print culture.

In The Winter's Tale, Mopsa says, "I love a ballad in print, / a-life, for then we are sure they are true" (WT, 4.4.260-61; Shakespeare 2010, 276). This line, spoken by a ballad-lover, may remind us of the Shakespeare editors, Capell, Steevens, and Malone. In their historical criticisms of Shakespeare and their emendation of his texts, they made occasional use of the Shakespearean ballads in the Reliques as reliable, printed authorities. Thus, the ballads came to assume an increasingly literate character as printed materials to be inquired, scrutinized, and researched by editors and scholars of Shakespeare, and their scholarly verification was ensured by the printed ballads in the Reliques.

Aichi Prefectural University

\section{Bibliography}

Broокs, Cleanth, ed. 1946. The Correspondence of Thomas Percy and Richard Farmer. Percy Letters 2. Baton Rouge: Louisiana State University Press.

Capell, Edward, ed. 1768. Mr William Shakespeare His Comedies, Histories, and Tragedies. 10 vols. London: J. and R. Tonson.

De Bruyn, Frans. 2012. "Reference Guide to Shakespeare in the Eighteenth Century". In Shakespeare in the Eighteenth Century. Edited by Fiona Ritchie and Peter SA BOR, 349-436. Cambridge: Cambridge University Press.

Donatelli, Joseph M. P. 1993. "The Percy Folio Manuscript: A Seventeenth-Century Context for Medieval Poetry". In English Manuscript Studies 1100-1700, vol. 4. Edited by Peter Beal and Jeremy Griffiths, 114-33. London: British Library.

Editions and Adaptations of Shakespeare. 1996. CD-ROM. Cambridge: Chadwyck-Healey.

Friedman, Albert B. 1961. The Ballad Revival: Studies in the Influence of Popular on Sophisticated Poetry. Chicago: University of Chicago Press.

Fumerton, Patricia, ed. 2003. "English Broadside Ballad Archive". University of California, Santa Barbara. Accessed June 8, 2016. http://ebba.english.ucsb.edu/ballad/20167/citation.

Groom, Nick. 1999. The Making of Percy's Reliques. Oxford: Oxford University Press. Hager, Alan, ed. 2005. Encyclopedia of British Writers. Vol. 1, Sixteenth and Seventeenth Centuries. New York: Facts on File. 
Hales, John W., and Frederick J. Furnivall, eds. 1867-68. Bishop Percy's Folio Manuscript: Ballads and Romances. 3 vols. London: N. Trübner.

Hinman, Charlton, ed. 1968. The Norton Facsimile: The First Folio of Shakespeare. New York: W. W. Norton.

Johnson, Samuel, ed. 1765. The Plays of William Shakespeare. 8 vols. London: J. and R. Tonson.

Johnson, Samuel, and George Steevens, eds. 1773. The Plays of William Shakespeare. 1 st ed. 10 vols. London: C. Bathurst.

- eds. 1778. The Plays of William Shakspeare. 2nd ed. 10 vols. London: C. Bathurst. -, eds. 1785. The Plays of William Shakspeare. 3rd ed. 10 vols. London: C. Bathurst.

- eds. 1793. The Plays of William Shakspeare. 4th ed. 15 vols. London: T. Longman.

Kastan, David Scott. 2001. Shakespeare and the Book. Cambridge: Cambridge University Press.

Malone, Edmond, ed. 1790. The Plays and Poems of William Shakspeare. 10 vols. London: J. Rivington and Sons.

McDowell, Paula. 2006. "The Manufacture and Lingua-Facture of Ballad-Making': Broadside Ballads in Long Eighteenth-Century Ballad Discourse". Eighteenth Century 47.2, 151-78.

- 2010. "Mediating Media Past and Present: Toward a Genealogy of 'Print Culture' and 'Oral Tradition". In This Is Enlightenment. Edited by Clifford Siskin and William Warner, 229-46. Chicago: University of Chicago Press.

McLane, Maureen N. (2008) 2011. Balladeering, Minstrelsy, and the Making of British Romantic Poetry. Reprint, Cambridge: Cambridge University Press.

- 2010. "Mediating Antiquarians in Britain, 1760-1830: The Invention of Oral Tradition; or, Close Reading before Coleridge". In This Is Enlightenment. Edited by Clifford Siskin and William Warner, 247-64. Chicago: University of Chicago Press.

Neberer, Eric. 2011. "The Broadside Ballad and Textual Publics". Studies in English Literature 1500-1900 51.1, 1-19.

Neuberg, Victor E. 1977. Popular Literature. Harmondsworth: Penguin Books.

Newman, Steve. 2007. Ballad Collection, Lyric, and the Canon: The Call of the Popular from the Restoration to the New Criticism. Philadelphia: University of Pennsylvania Press.

Ong, Walter J. 1971. Rhetoric, Romance, and Technology: Studies in the Interaction of Expression and Culture. Ithaca, NY: Cornell University Press.

- 1982. Orality and Literacy: The Technologizing of the Word. London: Methuen.

Percy, Thomas, ed. 1765. Reliques of Ancient English Poetry: Consisting of Old Heroic Ballads, Songs, and Other Pieces of Our Earlier Poets, (Chiefly of the Lyric Kind.) Together with Some Few of Later Date. 1st ed. 3 vols. London: J. Dodsley.

— Songs, and Other Pieces of Our Earlier Poets, (Chiefly of the Lyric Kind.) Together with Some Few of Later Date. 2nd ed. 3 vols. London: J. Dodsley. 
ed. 1775. Reliques of Ancient English Poetry: Consisting of Old Heroic Ballads, Songs, and Other Pieces of Our Earlier Poets, Together with Some Few of Later Date. 3rd ed. 3 vols. London: J. Dodsley.

— - ed. 1794. Reliques of Ancient English Poetry: Consisting of Old Heroic Ballads, Songs, and Other Pieces of Our Earlier Poets, Together with Some Few of Later Date. 4th ed. 3 vols. London: F. and C. Rivington.

- ed. 1812. Reliques of Ancient English Poetry: Consisting of Old Heroic Ballads, Songs, and Other Pieces of Our Earlier Poets; Together with Some Few of Later Date. 5th ed. 3 vols. London: F. C. and J. Rivington.

- ed. 1891. Reliques of Ancient English Poetry, Consisting of Old Heroic Ballads, Songs, and Other Pieces of Our Earlier Poets Together with Some Few of Later Date. Edited by Henry B. Wheatley. 3 vols. London: Swan Sonnenschein.

Pope, Alexander, ed. 1725. The Works of Shakespear. 6 vols. London: Jacob Tonson.

Porter, Gerald. 1997. "Telling the Tale Twice Over: Shakespeare and the Ballad”. In Ballads into Books: The Legacies of F. J. Child. Edited by Tom Cheesman and Sigrid Rieumerts, 165-78. Bern: Peter Lang.

Regan, John. 2014. "Ambiguous Progress and Its Poetic Correlatives: Percy's Reliques and Stadial History". English Literary History 81.2, 615-34.

Robinson, M. G., and Leah Dennis, eds. 1951. The Correspondence of Thomas Percy and Thomas Warton. Percy Letters 3. Baton Rouge: Louisiana State University Press.

Row e, Nicholas, ed. 1709. The Works of Mr. William Shakespear. 6 vols. London: Jacob Tonson.

Shakespeare, William. 1597. An Excellent Conceited Tragedie of Romeo and Iuliet. London: Iohn Danter. http://special-1.bl.uk/treasures/SiqDiscovery/ui/PageMax.asp $\mathrm{x}$ ?strResize $=$ yes\& $\operatorname{str}$ Copy $=79 \&$ page $=18$.

1599. The Most Excellent and Lamentable Tragedie, of Romeo and Iuliet. London: Cuthbert Burby. http://special-1.bl.uk/treasures/SiqDiscovery/ui/PageMax.aspx?strR esize $=$ yes\& $\operatorname{strCopy}=80 \&$ page $=22$.

1602. A Most Pleasaunt and Excellent Conceited Comedie, of Syr Iohn Falstaffe, and the Merrie Wiues of Windsor. London: Arthur Iohnson. http://special-1.bl.uk/ treasures/SiqDiscovery/ui/PageMax.aspx?strResize=yes\&strCopy=39\&page=24.

1622. The Tragoedy of Othello, the Moore of Venice. London: Thomas Walkley. http://special-1.bl.uk/treasures/SiqDiscovery/ui/PageMax.aspx?strResize=yes\&strCo py $=49$ \& page $=30$.

- 1630. The Tragoedy of Othello, the Moore of Venice. London: Richard Hawkins. http://special-1.bl.uk/treasures/SiqDiscovery/ui/PageMax.aspx?strResize=yes\&strCo py $=50$ \& page $=77$.

- 1871. Romeo and Juliet. Edited by Horace Howard Furness. New Variorum Edition of Shakespeare 1. Philadelphia: J. B. Lippincott.

. (1997) 1999. Othello. Edited by E. A. J. Honigmann. Arden Shakespeare 3. Walton-on-Thames, UK: Thomas Nelson and Sons. 
2010. The Winter's Tale. Edited by John Pitcher. Arden Shakespeare 3. London: Bloomsbury.

Sherbo, Arthur. 1986. The Birth of Shakespeare Studies: Commentators from Rowe (1709) to Boswell-Malone (1821). East Lansing, MI: Colleagues Press.

Steevens, George, ed. 1766. Twenty of the Plays of Shakespeare, Being the Whole Number Printed in Quarto during His Life-Time, or before the Restoration, Collated Where There Were Different Copies, and Publish'd from the Originals. 4 vols. London: J. and R. Tonson.

Sternfeld, F. W. 1964. "Music and Ballads". Shakespeare Survey 17, 214-22.

Stewart, Keith. 1958. "Ancient Poetry as History in the Eighteenth Century". Journal of the History of Ideas 19.3, 335-47.

TAY LOR, Gary. 1989. Reinventing Shakespeare: A Cultural History, from the Restoration to the Present. New York: Weidenfeld and Nicolson.

Theobald, Lewis, ed. 1733. The Works of Shakespeare. 7 vols. London: A. Bettesworth.

Tillotson, Arthur, ed. 1944. The Correspondence of Thomas Percy and Edmond Malone. Percy Letters 1. Baton Rouge: Louisiana State University Press.

Walsh, Marcus. 1997. Shakespeare, Milton, and Eighteenth-Century Literary Editing: The Beginnings of Interpretative Scholarship. Cambridge: Cambridge University Press.

Warburton, William, ed. 1747. The Works of Shakespear. 8 vols. London: J. and P. Knapton.

Warton, Thomas. (1774-81) 1998. The History of English Poetry from the Close of the Eleventh to the Commencement of the Eighteenth Century. 3 vols. Facsimile of the first edition, with an introduction by David Fairer. London: Routledge/Thoemmes Press.

Weinstein, Helen, ed. 1992. Catalogue of the Pepys Library at Magdalene College Cambridge. Vol. 2, pt. 1, Ballads. Cambridge: D.S. Brewer. 